\title{
Methane and Carbon Dioxide Fluxes from a European Alpine Fen Over the Snow-Free Period
}

\author{
Ruth Henneberger $^{1} \cdot$ Simrita Cheema $^{1}$ - Alessandro G. Franchini ${ }^{1,2}$. \\ Anita Zumsteg ${ }^{1,3}$. Josef Zeyer ${ }^{1}$
}

Received: 24 March 2015 / Accepted: 10 September 2015 / Published online: 17 September 2015

(C) Society of Wetland Scientists 2015

\begin{abstract}
Wetlands play an important role in the global carbon cycle and are sources and sinks for the greenhouse gases methane $\left(\mathrm{CH}_{4}\right)$ and carbon dioxide $\left(\mathrm{CO}_{2}\right)$. We provide an in situ study on variability of daytime $\mathrm{CH}_{4}$ emissions and net ecosystem $\mathrm{CO}_{2}$ exchange (NEE) from a permanently submerged, Carex rostrata dominated Swiss alpine fen over the snow-free period (June-October). Flux chamber measurements were combined with analyses of above-ground biomass and physico-chemical pore water properties. The fen was a net daytime $\mathrm{CH}_{4}$ source throughout the snow-free period, and emissions varied significantly between the sampling dates, ranging from $3.1 \pm 0.9 \mathrm{mg} \mathrm{CH}_{4} \mathrm{~m}^{-2} \mathrm{~h}^{-1}$ in October to $8.0 \pm$ $2.9 \mathrm{mg} \mathrm{CH}_{4} \mathrm{~m}^{-2} \mathrm{~h}^{-1}$ in August. The fen was generally a daytime sink for $\mathrm{CO}_{2}$, and net $\mathrm{CO}_{2}$ emission was only observed in late October. Variations in NEE were more pronounced than variations in $\mathrm{CH}_{4}$ emissions, but both fluxes
\end{abstract}

Electronic supplementary material The online version of this article (doi:10.1007/s13157-015-0702-y) contains supplementary material, which is available to authorized users.

Josef Zeyer

zeyer@env.ethz.ch

Alessandro G. Franchini

alessandro.franchini@hotmail.com

Anita Zumsteg

anita.zumsteg@alumni.ethz.ch

1 Institute of Biogeochemistry and Pollutant Dynamics, ETH Zürich, Universitätstrasse 16, CH-8092 Zürich, Switzerland

2 Present address: Surgical Intensive Care Medicine, University Hospital Zurich, University of Zurich, Zurich, 8091 Switzerland

3 Present address: Omya International AG, Baslerstrasse 42, 4665 Oftringen, Switzerland correlated with changes in green C. rostrata biomass and subsurface temperatures. Methane and $\mathrm{CO}_{2}$ pore water concentrations also varied significantly over the snow-free period, decreasing and increasing, respectively. These variations were linked to the development of biomass, but $\mathrm{CH}_{4}$ emissions and NEE were not correlated with the respective pore water concentrations.

Keywords Wetlands - Greenhouse gas emissions · Pore water profiles $\cdot$ Carbon cycling $\cdot$ Carex rostrata

\section{Introduction}

Wetlands in the northern hemisphere have been suggested to store roughly one third of the global terrestrial organic carbon (Gorham 1991; Blodau 2002). Photosynthetic activity of the wetland flora (mainly sedges, mosses and algae) generally leads to an uptake of atmospheric carbon dioxide $\left(\mathrm{CO}_{2}\right)$ into the system. Conversly, $\mathrm{CO}_{2}$ is produced through respiration, which includes dark-respiration of wetland plants and microbial mineralization of soil organic matter (Schlesinger 1997; Blodau 2002). The $\mathrm{CO}_{2}$ flux across the soil-atmosphere interface (net ecosystem $\mathrm{CO}_{2}$ exchange NEE) is considered the net of gross photosynthesis by green plant material and total respiration of the system (e.g., Rustad et al. 2000): A negative value indicates uptake (i.e., photosynthesis is greater than respiration), while a positive value indicates emission (i.e., photosynthesis is smaller than respiration). In the cold, water-saturated, anoxic soils of northern wetlands respiration rates are generally reduced (Blodau 2002; Moore and Basiliko 2006), leading to carbon accumulation in the system. On the other hand, wetlands are the largest non-anthropogenic source of methane $\left(\mathrm{CH}_{4}\right)$, with estimated annual emissions of $177-$ $284 \mathrm{Tg}$ (Ciais et al. 2013). Methane is thereby produced in 
the anoxic zones of the soils as final step of microbial organic matter degradation (Conrad 1996).

In northern wetlands $\mathrm{CH}_{4}$ and $\mathrm{CO}_{2}$ dynamics show high spatial and temporal variability, as they are affected by multiple, often interrelated environmental factors, such as temperature, water table level, $\mathrm{pH}$ and other soil characteristics (e.g., Christensen et al. 1995; Shaver et al. 1998; Hirota et al. 2006; von Fischer et al. 2010). For example, reduced photosynthesis rates with increased water table have been reported (Oberbauer et al. 1992; Blodau et al. 2004), while higher respiration rates in peat soil have been shown for regularly changing water table levels (Aerts and Ludwig 1997). The influence of the water table on $\mathrm{CH}_{4}$ emissions is less clear, and enhanced (e.g., McEwing et al. 2015) or reduced (e.g., Bellisario et al. 1999) emissions with increased water table level have been demonstrated.

Wetland plants in general and aerenchymous vascular plants in particular, also play a crucial role in $\mathrm{CH}_{4}$ emissions and NEE (e.g., Blodau 2002; Ström et al. 2003; Laine et al. 2012). Not only do they influence the $\mathrm{CO}_{2}$ dynamics through photosynthesis and respiration, they also affect the different processes involved in the cycling of $\mathrm{CH}_{4}$ (Joabsson et al. 1999). The aerenchyma is an adaptation to aquatic habitats and facilitates transport of oxygen $\left(\mathrm{O}_{2}\right)$ to submerged roots in anoxic soil (Armstrong et al. 1991), thus stimulating $\mathrm{CH}_{4}$ oxidation by aerobic $\mathrm{CH}_{4}$ oxidizing bacteria (methanotrophs) in the rhizosphere (Whalen 2005). Yet, it also acts as a conduit for the direct release of $\mathrm{CH}_{4}$ generated in the subsurface to the atmosphere, bypassing methanotrophic zones (e.g., King et al. 1998; Green and Baird 2011). Moreover, root exudates and decaying plant biomass increase the substrate pool for heterotrophic microorganisms and ultimately for methanogens (King and Reeburgh 2002; Saarnio et al. 2004). Even species-specific variations in $\mathrm{CH}_{4}$ emissions and NEE have been reported for the typical wetland sedges Carex, Eriophorum and Juncus, attributed to differences in root exudation pattern and radial oxygen loss (Ding et al. 2005; Ström et al. 2005; Koelbener et al. 2010). Recently, differences in the active methanotrophic and methanogenic microbial communities associated with Carex and Eriophorum spp. have also been demonstrated (Cheema et al. 2015).

As source for $\mathrm{CH}_{4}$ and sink for $\mathrm{CO}_{2}$, northern wetlands play an important role in the global carbon cycling (Denman et al. 2007). However, the net of carbon sequestration versus emission varies between different types of wetlands and can change over time (Mitra et al. 2005). In particular, for alpine wetlands knowledge on $\mathrm{CH}_{4}$ and $\mathrm{CO}_{2}$ dynamics is limited. Alpine wetlands often form in high mountain valleys with remnant glaciers and intermountain basins along rivers and streams (Windell et al. 1986; Wickland et al. 2001), but estimates on their global extent are lacking. They differ from the vast (sub-)arctic wetland areas in various aspects: They are characterized by generally higher temperatures, diurnal light cycles, lack of permafrost, and the presence of an insulating snow cover for prolonged periods.
However, analogue processes mediated by photosynthetic plants and specific microbial communities are driving the carbon cycle, and comparable life zones and plant communities thrive during the short vegetation periods in the Alps and northern Tundra regions (Körner 1999). In particular, sedges of the family Cyperaceae are commonly found in wetland systems throughout the northern hemisphere at different latitudes and altitudes (e.g., Wickland et al. 2001; Kutzbach et al. 2004; Franchini et al. 2014). Thus, to a certain degree alpine wetlands can be considered model systems to enhance our knowledge on the carbon cycling in northern wetland areas.

Studies on $\mathrm{CH}_{4}$ and $\mathrm{CO}_{2}$ dynamics in alpine wetlands have mainly been performed in the Rocky Mountains (e.g., West et al. 1999; Chimner and Cooper 2003) and the Tibetan Plateau (e.g., Hirota et al. 2006; Cao et al. 2008; Chen et al. 2011; Kato et al. 2011), reporting similar $\mathrm{CH}_{4}$ emissions compared with emissions measured in northern Tundra environments (e.g., Bellisario et al. 1999; Joabsson and Christensen 2001; Wickland et al. 2001; Hirota et al. 2004). For Europe, such studies are scarce and limited to $\mathrm{CH}_{4}$ and $\mathrm{CO}_{2}$ fluxes from an Austrian alpine fen (Koch et al. 2007, 2008) and $\mathrm{CH}_{4}$ dynamics in the Swiss Alps (Liebner et al. 2012; Franchini et al. 2015). Recently, we also conducted a survey of $\mathrm{CH}_{4}$ emissions during July and August from 14 fens in different regions of the Swiss Alps (Franchini et al. 2014). In this study we demonstrated that the amount of above-ground biomass and mean $\mathrm{CH}_{4}$ pore water concentrations between 0 and $20 \mathrm{~cm}$ depth were main factors correlating with the observed spatial variability in emissions.

For the present study, we selected one permanently submerged fen from this survey, which showed comparable $\mathrm{CH}_{4}$ emissions in mid-summer in two consecutive years. Yet, variations during the short snow-free vegetation period have not been analysed, and information on NEE in this particular fen are lacking. For our study site we hypothesize: (i) that $\mathrm{CH}_{4}$ emissions and NEE vary along the snow-free period; (ii) that these variations are more pronounced for NEE than for $\mathrm{CH}_{4}$ emissions, since meteorological changes along the snowfree period have a more distinct effect on the development of the above-ground vegetation than the below-ground processes; (iii) that these variations are also correlated with changes in $\mathrm{CH}_{4}$ and $\mathrm{CO}_{2}$ pore water concentrations. To assess these hypotheses, net $\mathrm{CH}_{4}$ emissions and NEE were measured with static flux chambers at seven time points throughout the snowfree period and complemented by analyses of $C$. rostrata biomass and physico-chemical pore water properties.

\section{Materials and Methods}

\section{Study Site and Sampling Location}

The field based experiments were carried out in an alpine fen located near the Oberaar lake in the Canton of Bern, 
Switzerland, at 2,320 $\mathrm{m}$ a.s.1.. The study site was described in detail previously (Franchini et al. 2015). In brief, at the Oberaar site, two interconnected minerotrophic fens (fen 1 with approx. 3,600 $\mathrm{m}^{2}$ and fen 2 with approx. 1,000 $\mathrm{m}^{2}$ ) are situated on siliceous bedrock. Fen 1 receives water from two main inlets; the water subsequently flows from fen 1 to fen 2 and is discharged from fen 2 through the main outlet (see Franchini et al. 2015 for map). In both fens, the soil is continuously submerged, and the vegetation is dominated by sedges of the Cyperaceae family (i.e., Carex rostrata, C. nigra and C. sempervivens, Eriophorum angustifolium and E. scheuchzeri, and Trichophorum caespitosum), covering roughly $70 \%$ of the surface area. The mosses Calliergon sarmentosum and Sphagnum spp. are also present in patches.

The sampling location for the present study was positioned in fen 1 at $46^{\circ} 32^{\prime} 50.7^{\prime \prime} \mathrm{N}$ and $08^{\circ} 15^{\prime} 41.1^{\prime \prime} \mathrm{E}$, and covered an area of ca. $15 \mathrm{~m}^{2}$. At this location, a constant water table level of ca. 4-5 cm above the soil surface and a slight water flow of $0.5 \mathrm{~m} \mathrm{~min}^{-1}$ was observed. The dominant vascular plant was C. rostrata, with the submerged moss $C$. sarmentosum also being present. This specific location was chosen because of its central rather than marginal position within the fen and accessibility via a small island without disturbance to the system (location in close proximity to sampling location shown in Franchini et al. 2015). Moreover, plant biomass appeared to be rather homogeneous with respect to type and distribution (Fig. S1).

Seven sampling dates were selected throughout the snowfree period of 2012: Jun 26, Jul 18, Aug 8, Aug 23, Sep 12, Sep 25, and Oct 22. A float, constructed of Styrofoam and aluminium ladders, was used to support the weight of samplers and equipment in order to avoid disturbing and damaging the fen. On each sampling date, four independent flux chamber measurements were performed, and surface and pore water samples were collected along the depth profile at four positions (see below). The four flux chambers were positioned in close proximity to each other on each sampling date, but positions varied slightly between the different dates, as the biomass enclosed inside the chamber was cut after the measurements to determine its dry weight. Surface and pore water sampling was performed at the same four positions on each sampling date (setup comparable with Fig. 2 in Franchini et al. 2015). Experiments were largely conducted between $10 \mathrm{am}$ and $4 \mathrm{pm}$, with flux chamber measurements being carried out between 11:30 am and 2:30 pm.

\section{Meteorological Data}

Meteorological data was obtained from the Grimsel-Hospiz World Meteorological Organization (WMO) station 06744 $\left(46^{\circ} 34^{\prime} 18^{\prime \prime} \mathrm{N}, 08^{\circ} 19^{\prime} 59.5^{\prime \prime} \mathrm{E}\right.$; approx. $6 \mathrm{~km} \mathrm{NE}$ of the study site at $1,980 \mathrm{~m}$ a.s.1.). In 2012, the total annual precipitation was $2,190 \mathrm{~mm}$, and a mean temperature of $2.3{ }^{\circ} \mathrm{C}$ with a minimum of $-26.1^{\circ} \mathrm{C}$ and a maximum of $23.5^{\circ} \mathrm{C}$ was recorded at this station.

We acquired data of the daily mean temperature $2 \mathrm{~m}$ above ground, precipitation and global radiation over the snow-free period. Moreover, for the sampling dates we used 10 minutemean values to calculate average temperature and global radiation for the time interval of the flux chamber measurements (11:30 am-2:30 pm). Temperature data was corrected for the difference in elevation between the sampling location and WMO station, assuming a temperature decrease of $-0.6{ }^{\circ} \mathrm{C} /$ $100 \mathrm{~m}$ increase of elevation.

\section{Quantification of $\mathrm{CH}_{4}$ Emission and NEE}

Net fluxes of $\mathrm{CH}_{4}$ and $\mathrm{CO}_{2}$ were measured using transparent static chambers (ca. $30 \mathrm{~cm} \times 30 \mathrm{~cm} \times 30 \mathrm{~cm}$; volume of $0.027 \mathrm{~m}^{3}$ ) made of acrylic glass that is highly transmissive for photosynthetically active light (98\% under sunny conditions; Kunstoplex, Greifensee, Switzerland). Measurements were done as described previously (Liebner et al. 2012; Franchini et al. 2014). In brief, the chambers were carefully placed in the standing water of the fen without disturbing the system, and the standing water thereby provided a complete sealing of the chambers. The total gas volume inside the chamber was calculated for each experiment by measuring the average height between the water table and the top of the chamber.

After equilibration of $5 \mathrm{~min}$, the ventilation hole was closed with a butyl rubber stopper, and the first gas sample $(50 \mathrm{~mL})$ was extracted from the chamber headspace with a gas-tight syringe equipped with a three-way valve (Discofix C-3, Braun Melsungen AG, Germany), followed by sample extraction every $5 \mathrm{~min}$ over a total of $30 \mathrm{~min}$. Immediately prior to each sampling event, the piston of the syringe was pumped five times to mix the gas inside the chamber. Each gas sample was transferred immediately into a $20 \mathrm{~mL}$ glass vial, which had been previously flushed with $\mathrm{N}_{2}$ and evacuated.

Methane and $\mathrm{CO}_{2}$ concentrations were measured in the same gas sample by gas chromatography (GC). Methane was quantified using a flame ionization detector (FID; Trace GC Ultra, Thermo Electron Corporation, Rodano, Italy) following separation over a packed steel column (2 m long, 1/16" o.d., 1 mm i.d.; packed with Porapak N 100/120 mesh), using $\mathrm{N}_{2}$ as the carrier gas $\left(3.2 \mathrm{~mL} \mathrm{~min}^{-1}\right)$; column and detector temperatures were $30{ }^{\circ} \mathrm{C}$ and $250{ }^{\circ} \mathrm{C}$, respectively. Carbon dioxide was also quantified by GC-FID, but on a different instrument equipped with methanizer (SRI Instruments, Menlo Park CA) to ensure higher sensitivity, after separation over a $9 \mathrm{ft}$ Hayesep D column, using $\mathrm{N}_{2}$ as carrier gas and column and detector temperatures of $40{ }^{\circ} \mathrm{C}$ and $300{ }^{\circ} \mathrm{C}$, respectively.

The net $\mathrm{CH}_{4}$ and $\mathrm{CO}_{2}$ fluxes were subsequently computed by linear regression of the concentration changes of the 
respective gas inside the chamber (van der Nat and Middelburg 1998; Ding et al. 2005; Liebner et al. 2012), using samples collected over the entire $30-\min$ period and the first 15 min, respectively (see control experiments below).

\section{Control Experiments for Flux Measurements}

Additional control experiments for flux measurements were performed at the Oberaar fen during summer 2014 to assess the impact of incubation time, mixing of air, and potential temperature and pressure changes inside the chambers on flux calculations. These experiments were generally carried out in quadruplicates in close proximity to the location that was sampled in 2012 for the present study. The following modifications from previous flux measurements were introduced: The ventilation hole was closed immediately after placing the chamber into the fen, and the incubation time was increased to $1 \mathrm{~h}$. In addition, each chamber was equipped with a small, battery-driven fan to ensure a continuous mixing of the air inside the chamber, and fluxes were measured at each location with and without mixing. Eight Thermochron iButton dataloggers (DS1922L\#F50, Maxim, Sunnyvale, CA) were placed at different positions throughout the chamber, and temperatures were recorded every minute during flux measurements. Pressure inside the chambers was measured periodically using a handheld manometer (LEO1, Keller AG, Winterthur, Switzerland) equipped with a fine needle that was inserted through the rubber stopper in the ventilation hole.

Methane concentrations in all chambers increased linearly over the period of $1 \mathrm{~h}$ from $6.5 \pm 0.9 \mathrm{ppmv}$ after $5 \mathrm{~min}$ of incubation to $>43$ ppmv after $1 \mathrm{~h}$ (representative examples shown in Fig. S2a and b, and in Franchini et al. 2015). The low starting concentrations and linearity of the increase suggest that initial gas release due to disturbance during chamber deployment or spontaneous ebullition during chamber incubation did not occur. Linearity of the $\mathrm{CO}_{2}$ concentration decrease was only observed in the first 15-20 min of the incubation, followed by rather constant concentrations between 75 and $150 \mathrm{ppmv}$ for the reminder of the incubation period (representative examples shown in Fig. S2c and d). Based on the results of these control experiments, in the present study we calculated the $\mathrm{CH}_{4}$ emissions using all gas samples taken from the chamber headspace over the 30-min period of the chamber incubation. For the calculation of NEE, only gas samples taken from the chambers within the first 15 min were used.

During selected experiments, headspace samples were also collected after 0.5 and 2.5 min incubation time, and results showed a rapid depletion of $\mathrm{CO}_{2}$ inside the chambers within the initial 5-10 $\mathrm{min}$ (data not shown). Calculations of net $\mathrm{CO}_{2}$ uptake rates using the 0.5 to $15 \mathrm{~min}$ and the 5 to $15 \mathrm{~min}$ time interval suggest a potential underestimation of the rates by ca. $20 \%$ for the latter time interval.
During the control experiments, temperatures inside the chambers showed little variation throughout the hour-long incubation (Fig. S2), but slightly higher temperatures were observed when a fan was used. At the Oberaar fen, the temperature of the surface water was generally higher than the air temperature, particularly during sunny conditions, and the turbulences introduced by the fan likely explain the higher average temperatures inside the chambers during fan experiments. Nevertheless, the use of a fan did not influence development of $\mathrm{CH}_{4}$ and $\mathrm{CO}_{2}$ concentrations (Fig. S2). Moreover, the pressure inside the chambers coincided with the air pressure and was constant ( \pm 1 mbar) from the time point immediately after closing the ventilation hole to the end of incubation independently of sample extraction. We therefore assume that the deployment of the chambers did not result in pressure peaks due to disturbance to the system.

\section{Plant Biomass and its Influence on $\mathrm{CH}_{4}$ Emission and NEE}

After flux measurements, the chambers were carefully removed and the $C$. rostrata biomass enclosed inside the chambers was cut at the water table. The biomass was separated into "green" and "brown", dried at $60{ }^{\circ} \mathrm{C}$ for $72 \mathrm{~h}$ and weighed. Green biomass was defined as healthy-looking and predominately green material, whereas brown material included all decaying, brown and dry material. The chlorophyll content of the green and brown biomass was measured according to Pocock et al. (2004) and Porra (2006). Green biomass had a chlorophyll content $\geq 1.5 \mathrm{mg}$ (g dry biomass) ${ }^{-1}$, while in the brown biomass the chlorophyll content was $\leq 0.5 \mathrm{mg}$ (g dry biomass $)^{-1}$. For all chambers, a clear distinction was possible according to these criteria, and no $C$. rostrata biomass was observed with a chlorophyll content between 0.5 and $1.5 \mathrm{mg}$ (g dry biomass $)^{-1}$.

To determine the influence of $C$. rostrata biomass on $\mathrm{CH}_{4}$ fluxes and NEE, additional experiments were carried out in triplicates on three sampling dates (Aug 8, Aug 23 and Sep 25): After regular flux measurements with full plant biomass, C. rostrata was cut ca. $2 \mathrm{~cm}$ above the water table, the chamber placed back at the same position, and the flux measured again; subsequently, the remaining biomass was cut ca. $1 \mathrm{~cm}$ below the water table followed by another flux measurement.

\section{Sampling and Physico-Chemical Analyses of Surface and Pore Water}

Pore water samples were collected by extracting water through a series of brass needles that were carefully inserted into the fen soil at different depths $(5.0,7.5,10.0,15.0,20.0$, $30.0,40.0$ and $50.0 \mathrm{~cm}$ below the water table) without applying pressure to the system (for image of installation see Franchini et al. 2015). Each needle ( $3 \mathrm{~mm}$ i.d., $4 \mathrm{~mm}$ o.d.) 
was sealed at the tip and perforated in the lowest $10 \mathrm{~mm}$ with several 2-mm holes and connected to a Teflon tube, three-way valve and air-tight syringe on the upper end. In addition, two needles were placed in the standing water to sample surface water at $1 \mathrm{~cm}$ and $2.5 \mathrm{~cm}$ below the water table. After installation, all needles were slowly filled with pore water by suction with the attached syringe, in order to avoid introduction of air into the system. After installation of the needles, the system was allowed to stabilize for at least $1 \mathrm{~h}$. Immediately prior to sampling of fresh pore water, the water inside the brass tubes was discarded, and the pore water samples were collected from the respective depths by suction with syringes avoiding exposure to air at all times. We applied this particular method to minimize disturbance of the system potentially caused by insertion of larger devices into to the very dense, sponge-like soil of the Oberaar fen.

Five $\mathrm{mL}$ of surface or pore water was transferred immediately to gas tight $20 \mathrm{~mL}$ glass vials, previously flushed with $\mathrm{N}_{2}$ and containing $0.1 \mathrm{~mL}$ of $1 \mathrm{M} \mathrm{HCl}$ solution, and stored at $4{ }^{\circ} \mathrm{C}$ until further processing. Headspace $\mathrm{CH}_{4}$ concentrations were subsequently measured by GC-FID as described above (Trace GC Ultra). Headspace $\mathrm{CO}_{2}$ concentrations were measured on the same instrument, but with a thermal conductivity detector (GC-TCD) and HayeSep D column (100/120), with column and detector temperatures of $85^{\circ} \mathrm{C}$ and $250{ }^{\circ} \mathrm{C}$, respectively. Concentrations of the dissolved gases in the surface and pore water were subsequently calculated from the measured headspace concentration according to Liebner et al. (2012).

Gaseous $\mathrm{CO}_{2}$ in the headspace of the sample vial is in equilibrium with the dissolved $\mathrm{CO}_{2}$ in the aqueous phase. The dissolved $\mathrm{CO}_{2}$ is part of the dissolved inorganic carbon (DIC), which consists of $\mathrm{CO}_{2} \mathrm{aq}, \mathrm{H}_{2} \mathrm{CO}_{3}, \mathrm{HCO}_{3}{ }^{-}$and $\mathrm{CO}_{3}{ }^{2-}$ (Stumm and Morgan 1981). Assuming a temperature of $10^{\circ} \mathrm{C}$ and a $\mathrm{pH}$ of $5, \mathrm{CO}_{3}{ }^{2-}$ is negligible and $\mathrm{HCO}_{3}{ }^{-}$can be calculated to be ca. $3.5 \%$ (Stumm and Morgan 1981). This percentage was experimentally confirmed at the Oberaar fen to be $5.2 \pm 2.3 \%$ in pore water samples collected at 10, 25 and $50 \mathrm{~cm}$ depth at three different positions. Acidification of the water samples was done in order to reduce the low fraction of $\mathrm{HCO}_{3}{ }^{-}$even further and make it available for the headspace quantification. Throughout this paper DIC is therefore used as a proxy for dissolved $\mathrm{CO}_{2}$ in the surface and pore water. Please note, that the Oberaar fen is located on siliceous bedrock and the pore water has a $\mathrm{pH}$ of ca. 5 (see results). Therefore dissolution of $\mathrm{CaCO}_{3}$ due to acidification of the samples does not occur.

After sample collection for $\mathrm{CH}_{4}$ and DIC concentration measurements, $20 \mathrm{~mL}$ of water was extracted from each depth, filtered on site through $0.45 \mu \mathrm{m}$ nylon filters (Wicom Perfect Flow, Meienfeld, Switzerland; pre-washed with deionized water), and transferred to $20 \mathrm{~mL}$ glass vials containing $0.1 \mathrm{~mL}$ of $1 \mathrm{M} \mathrm{HCl}$. Samples were stored at $-20{ }^{\circ} \mathrm{C}$ prior to further processing, and the dissolved organic carbon (DOC) concentration was determined using a carbon analyser (Shimadzu Scientific Instruments, Columbia, MD).

Depth profiles of dissolved oxygen $\left(\mathrm{O}_{2}\right)$ were measured on site. The concentration of $\mathrm{O}_{2}$ in surface and pore water was thereby determined based on the quenching of light in the presence of $\mathrm{O}_{2}$ using a Fibox 3-trace v3 Minisensor Trace Oxygen Meter with Planar Oxygen-Sensitive Spot PSt3 (PreSens, Regensburg, Germany), that was gradually inserted into the fen in close proximity to the pore water sampling installations. Oxygen values were logged after equilibration to ambient conditions, and are reported as percentage of air saturation: $100 \%$ is the concentration of dissolved $\mathrm{O}_{2}$ in water after equilibration with ambient air. Water and soil temperature along the depth profile was determined using a handheld temperature sensor (Testo AG, Lenzkirch, Germany).

Electrical conductivity and $\mathrm{pH}$ of the pore water at selected depth $(5.0,10.0,20.0,30.0,40.0$ and $50.0 \mathrm{~cm}$ below the water table) were also determined in situ via Multi 350i probe (WTW Laboratory and Field Products, Nova Analytics, Woburn, MA) using the LR 325/01 conductivity cell and the SenTix $51 \mathrm{pH}$ electrode, respectively, as described (Liebner et al. 2012).

In general, collection of four depth profiles for each parameter was envisaged on each sampling date. However, due to difficult meteorological conditions or technical difficulties in the field, fewer profiles of temperature, $\mathrm{pH}$, electrical conductivity, and $\mathrm{O}_{2}$ pore water concentration were obtained on some sampling dates, in particular on Jun 26 and Sep 12 (Table S1).

\section{Statistical Analyses}

Statistical analyses were performed with the software $\mathrm{R}$ (version 2.15.2; R Development Core Team 2012) and the software SYSTAT (version 12; Systat Software Inc., San Jose, CA). Normality of the data was tested using the Shapiro-Wilk test. Methane emissions, NEE and average physico-chemical pore water properties were normally distributed, while the green $C$. rostrata dry biomass was square-root transformed to approximate a normal distribution. Variation in $\mathrm{CH}_{4}$ emission, NEE, C. rostrata biomass and selected physico-chemical surface and pore water properties between the different sampling dates were tested using one-way analysis of variance (ANOVA). In addition, Pearson correlation with bootstrapping ( 0.95 confidence interval) and Bonferroni probability test was used to assess the relationship between $\mathrm{CH}_{4}$ emission or NEE and C. rostrata biomass or selected physico-chemical pore water properties. Spearman rank correlation analyses were performed to determine trends along the depth profile of the physico-chemical surface and pore water properties using mean values of the replicate samples taken each depth. Correlations were considered statistically significant for $p<0.05$. 


\section{Results}

\section{Meteorological Conditions}

In 2012, the Oberaar fen was free of snow from Jun 24 and continuously covered with snow beginning Oct 26 (i.e., a snow-free period of 124 days; Fig. S3). On the first day of sampling (Jun 26), substantial amounts of snow were still present in the surrounding areas (Fig. S1a). Snowfall was observed on Sep 12, Sep 27 and Oct 8, and the area was intermittently covered by several $\mathrm{cm}$ of snow, which did not persist. Over the snow-free period, the mean air temperature ( $2 \mathrm{~m}$ above ground) increased from June to August, followed by a general decrease, while global radiation $\left(\mathrm{W} \mathrm{m}^{-2}\right)$ showed a decreasing trend. However, precipitation, global radiation and temperature differed greatly between different days, and temperatures occasionally dropped below $0{ }^{\circ} \mathrm{C}$ in September and October (Fig. S3).

Conditions, between the individual sampling dates were also quite variable (Table 1 ). In particular, on Sep 12 the mean temperature was low $\left(0.7^{\circ} \mathrm{C}\right)$, and rain or light snowfall was observed all day, while temperatures were again substantially higher at the later sampling dates (Sep 25 and Oct 22 with $5.8^{\circ} \mathrm{C}$ and $9.0^{\circ} \mathrm{C}$, respectively). With the exception of Jun 26 and Sep 12, sampling was performed under (partially) sunny and dry conditions. The fen was submerged during the entire snow-free period, and the water table at the sampling location was ca. 4-5 cm on all sampling dates.

\section{Carex Rostrata Biomass}

The above-ground biomass present at the sampling location was clearly dominated by $C$. rostrata. The amount of green (i.e., photosynthetically active) biomass per square meter thereby varied significantly $(F=9.66, p<0.001, n=27)$ between the different sampling dates over the snow-free period. More specifically, a general increase in green biomass from $17.2 \pm 9.8 \mathrm{~g} \mathrm{~m}^{-2}$ to $66.2 \pm 38.2 \mathrm{~g} \mathrm{~m}^{-2}$ was observed from the beginning of the snow-free period to the beginning of August. From late September to late October the amount of green biomass tended to decrease, reaching values as low as $4.1 \mathrm{~g} \mathrm{~m}^{-2}$ (Fig. 1a). However, particularly on Aug 08 and Sep 12, the individual positions sampled showed some variation in biomass, and positions selected for the Aug 23 sampling had overall lower density of $C$. rostrata plants compared with the Aug 08 or Sep 12 positions.

The amount of brown (i.e., photosynthetically inactive) C. rostrata biomass also varied significantly $(F=39.5$, $p<0.001, n=28$ ) between the sampling dates. During July and August, it was generally low (3.3-7.7 $\mathrm{g} \mathrm{m}^{-2}$ ), but later increased as plants were senescing (Figs. 1a and S1e). In particular, on the first sampling date, substantial amounts of brown biomass from the previous vegetation period were observed below the water table (Fig. S1b), but this biomass was not included in our calculations.

\section{Methane Emission and NEE}

Measurements of $\mathrm{CH}_{4}$ fluxes and $\mathrm{NEE}$ were generally carried out between 11:30 am and 2:30 pm on each sampling date. Methane fluxes were always positive, meaning emission of $\mathrm{CH}_{4}$ from the fen to the atmosphere. A linear increase of $\mathrm{CH}_{4}$ concentration in the chamber headspace over time was clearly observed during all measurements $\left(r^{2} \geq 0.9\right.$; with two exceptions where $r^{2}=0.85$ and 0.79$)$. The deduced emissions thereby differed significantly $(F=3.28, p<0.05, n=26)$ between the different sampling dates over the snow-free period. Highest emissions of $8.0 \pm 2.9 \mathrm{mg} \mathrm{CH}_{4} \mathrm{~m}^{-2} \mathrm{~h}^{-1}$ were measured on Aug 08 , followed by a general decrease to $3.1 \pm 0.9 \mathrm{mg}$ $\mathrm{CH}_{4} \mathrm{~m}^{-2} \mathrm{~h}^{-1}$ on Oct 22 (Fig. 1b). Interestingly, high emissions

Table 1 Meteorological conditions: Daily precipitation, air temperature $2 \mathrm{~m}$ above ground and global radiation recorded each sampling date in 2012 at the Grimsel-Hospiz World Meteorological Organization (WMO) station 06744

\begin{tabular}{|c|c|c|c|c|c|}
\hline \multirow[t]{2}{*}{ Sampling date } & \multirow[t]{2}{*}{ General conditions } & \multirow[t]{2}{*}{ Daily precipitation $\left(\mathrm{mm} \mathrm{m}^{-2}\right)$} & \multicolumn{2}{|c|}{ Air temperature $\left({ }^{\circ} \mathrm{C}\right) 2 \mathrm{~m}$ above ground ${ }^{\mathrm{a}}$} & \multirow{2}{*}{$\begin{array}{l}\text { Global radiation }\left(\mathrm{W} \mathrm{m}^{-2}\right) \\
11: 30 \mathrm{am}-2: 30 \mathrm{pm}^{\mathrm{b}}\end{array}$} \\
\hline & & & Daily mean & $11: 30 \mathrm{am}-2: 30 \mathrm{pm}^{\mathrm{b}}$ & \\
\hline Jun 26 & Rainy & 15 & 6.1 & $6.0 \pm 0.1$ & $158 \pm 43$ \\
\hline Jul 18 & Sunny, cloudless & 0 & 10.6 & $13.9 \pm 0.7$ & $935 \pm 38$ \\
\hline Aug 08 & Sunny, windy & 0 & 8.1 & $10.7 \pm 0.6$ & $910 \pm 40$ \\
\hline Aug 23 & Partially sunny, windy & 1 & 13.4 & $16.3 \pm 1.1$ & $637 \pm 296$ \\
\hline Sep 12 & Rainy and snowy & 31.9 & 0.7 & $-1.1 \pm 0.8$ & $142 \pm 49$ \\
\hline Sep 25 & Partially sunny & 0 & 5.8 & $7.1 \pm 0.7$ & $260 \pm 113$ \\
\hline Oct 22 & Sunny & 0 & 9.0 & $9.8 \pm 1.0$ & $524 \pm 26$ \\
\hline
\end{tabular}

\footnotetext{
${ }^{\text {a }}$ Temperature data was corrected for the difference in elevation between the sampling location and WMO station, assuming a temperature decrease of $-0.6{ }^{\circ} \mathrm{C} / 100 \mathrm{~m}$ increase of elevation

${ }^{\mathrm{b}}$ Average values obtained from 10-min interval measurements
} 

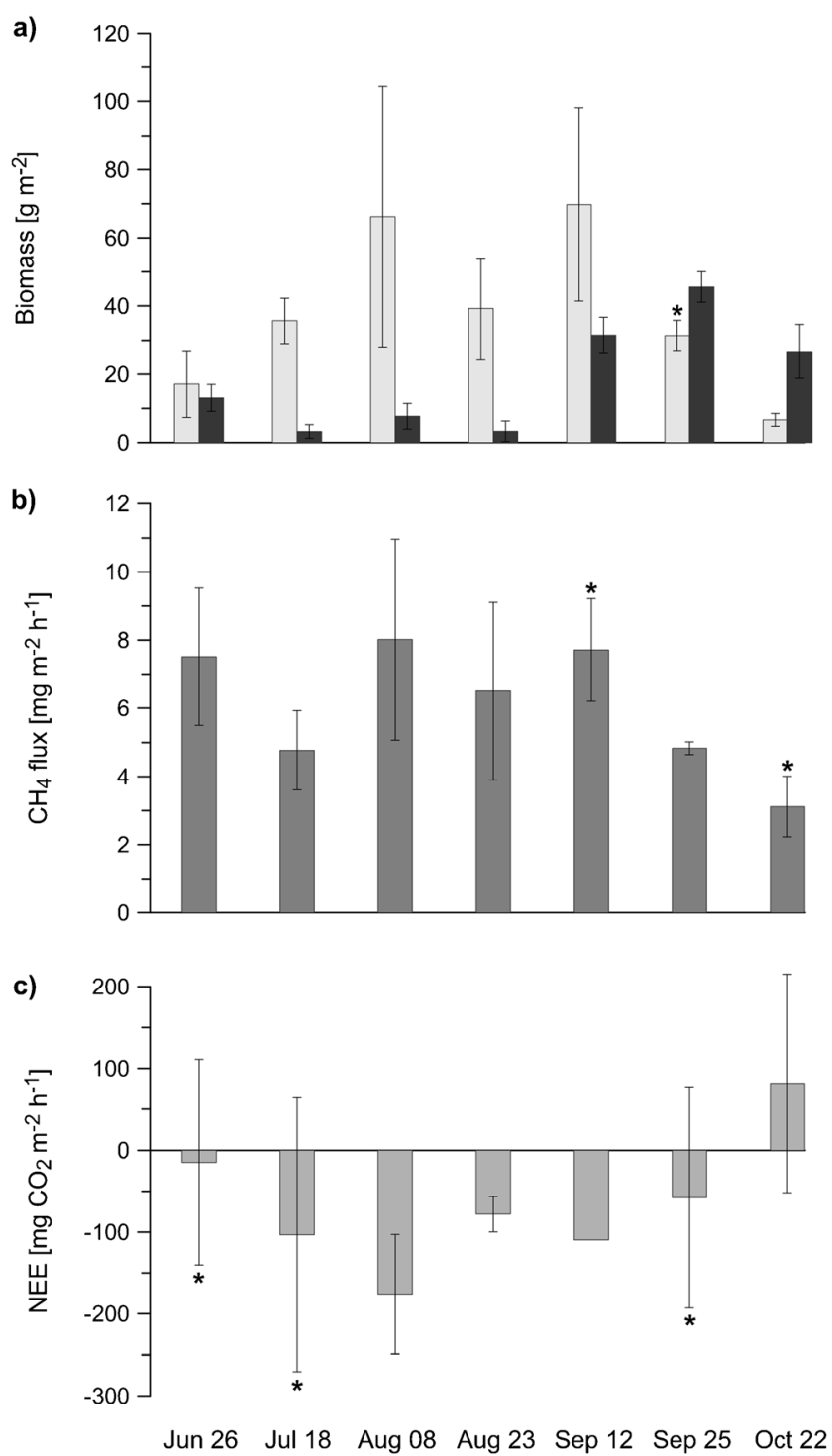

Fig. 1 Above-ground biomass of $C$. rostrata (a), $\mathrm{CH}_{4}$ emission (b), and NEE (c) determined on each sampling day. Biomass was separate into green (i.e., photosynthetically active, chlorophyll content $\geq 1.5 \mathrm{mg} \mathrm{g}^{-1}$ dry biomass; light grey bars) and brown biomass (i.e., photosynthetically inactive; chlorophyll content $\leq 0.5 \mathrm{mg} \mathrm{g}^{-1}$ dry biomass; dark grey bars). Error bars denote standard deviation ( $n=4$; with exception of *, where $n=$ 3 due to technical issues in the field and lab; please note that on Sep 12, only two values of NEE could be calculated due to technical issues with GC measurements)

of $7.5 \pm 2.0 \mathrm{mg} \mathrm{CH} \mathrm{CH}^{-2} \mathrm{~h}^{-1}$ were also measured in June shortly after snowmelt, while substantially lower emissions (4.8 $\pm 1.2 \mathrm{mg} \mathrm{CH}_{4} \mathrm{~m}^{-2} \mathrm{~h}^{-1}$ ) were observed in July.

Overall negative values of NEE (i.e., net $\mathrm{CO}_{2}$ uptake) were deduced from the chamber measurements for most of the snow-free period, ranging from $-5.9 \pm 106.2 \mathrm{mg} \mathrm{CO}_{2} \mathrm{~m}^{-2}$ $\mathrm{h}^{-1}$ on Jun 26 to $-176.0 \pm 73.0 \mathrm{mg} \mathrm{CO}_{2} \mathrm{~m}^{-2} \mathrm{~h}^{-1}$ on Aug 08 (Fig. 1c). This uptake generally showed an increasing trend from Jun 26 to Aug 08, followed by a decrease from Sep 12 to Sep 25. On Oct 22, overall positive NEE values (i.e., net $\mathrm{CO}_{2}$ emission) of $81.7 \pm 133.6 \mathrm{mg} \mathrm{CO}_{2} \mathrm{~m}^{-2} \mathrm{~h}^{-1}$ was measured. In the middle of the snow-free period, when the plant community was well established (Aug 8, Aug 23 and Sep 12), a clear linear decrease of $\mathrm{CO}_{2}$ concentration in the chamber headspace was observed over the first $15 \mathrm{~min}$ of the incubation period during most flux measurements $\left(r^{2}=0.71-0.99\right)$. Moreover, lower variation between the individual measurements taken on the same sampling date was noticed. However, early and late in the snow-free period, when plants were not yet well established or already senescing, NEE showed higher variation within the sampling dates. On these dates, both net $\mathrm{CO}_{2}$ emission (from 12.0 to $262.2 \mathrm{mg} \mathrm{CO}$ $\mathrm{m}^{-2} \mathrm{~h}^{-1}$ ) and uptake (from -44.2 to $-158.7 \mathrm{mg} \mathrm{CO}$ $\mathrm{m}^{-2} \mathrm{~h}^{-1}$ ) was measured in different chambers.

\section{Surface and Pore Water Concentrations of $\mathrm{CH}_{4}$, DIC and $\mathrm{O}_{2}$}

Steady-state concentrations of dissolved $\mathrm{CH}_{4}$ in the surface and pore water varied significantly $(F=18.4, p<0.001)$ between the different sampling dates over the snow-free period (Fig. 2a). On each sampling date, concentrations were lowest in the surface water ( 1 and $2.5 \mathrm{~cm}$ depth), followed by a significant increase with depth $[\rho=0.891-1.000, p \leq 0.001$; using mean values $(n=4)$ at each depth $(n=10)]$ (Fig. 2a). This increase was most pronounced immediately after snow melt, when concentrations were generally highest, ranging from $403 \pm 97 \mu \mathrm{M}$ at $20 \mathrm{~cm}$ depth to $577 \pm 22 \mu \mathrm{M}$ at $50 \mathrm{~cm}$ depth. As the season progressed, overall concentrations decreased, and similar values around $200 \mu \mathrm{M}$ were measured between 15 and $50 \mathrm{~cm}$ depth in most samples from Aug 23 to the end of the snow-free period.

Concentrations of DIC as proxy for dissolved $\mathrm{CO}_{2}$ also varied significantly $(F=3.71, p=0.001)$ between sampling dates, but in contrast to $\mathrm{CH}_{4}$, concentrations measured early in the snow-free period (Jun 26 and Jul 18) were generally lower compared with samples collected on the later dates (Fig. 2b). Nevertheless, on all sampling dates concentrations were lowest in the surface water, followed by a significant increase with depth $[\rho=0.952-0.988, p<0.001$; using mean values $(n=4)$ at each depth $(n=10)]$. This increase was particularly pronounced during August and September in the upper $20 \mathrm{~cm}$ of the depth profile. In this period, concentrations measured in the deeper layers (below $20 \mathrm{~cm}$ depth) were rather constant around 5,000 to $6,000 \mu \mathrm{M}$, with a maximum of $6,307 \pm 843 \mu \mathrm{M}$ measured on Sep 12 at $50 \mathrm{~cm}$ depth.

Steady-state $\mathrm{O}_{2}$ concentrations in the surface water were generally near or even slightly above air saturation, followed by a significant decrease with depth $[\rho=$ $0.802-1.000, p \leq 0.005$; using mean values $(n=3-4)$ at each depth $(n=10)]$ (Fig. 2c). This decrease was 
Fig. 2 Depth profiles of $\mathrm{CH}_{4}$ (a) DIC (b) and $\mathrm{O}_{2}(\mathbf{c})$ surface and pore water concentration determined for each sampling date. Dotted lines indicate approx. position of the soil surface. Error bars denote standard deviation $(n=4)$; please note that $\mathrm{O}_{2}$ measurements were done only at two positions on Aug 23 and at three on Sep 25; n.d.: not done a) $\mathrm{CH}_{4}$ concentration $[\mu \mathrm{M}]$
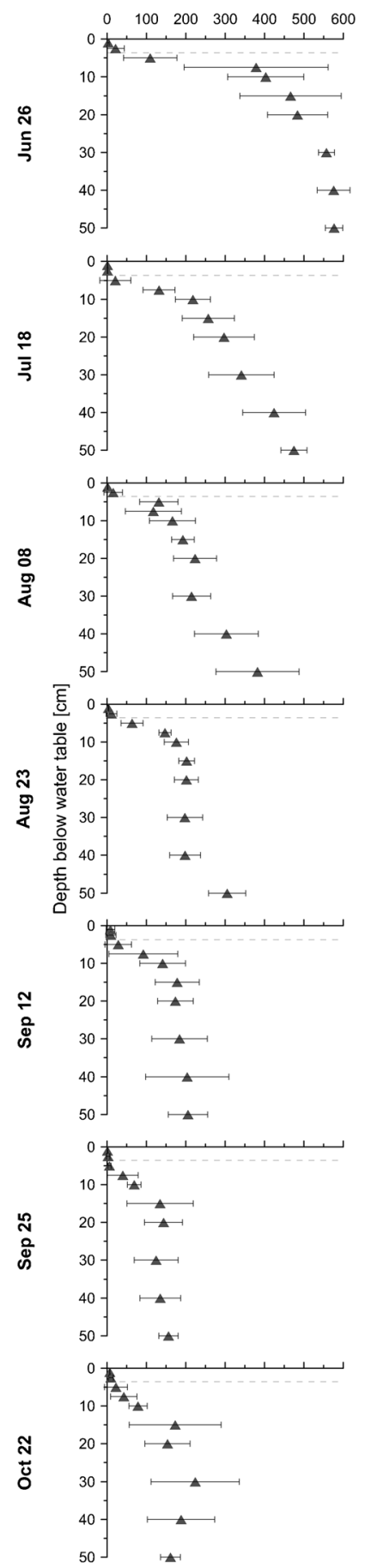

b) $\mathrm{DIC}$ concentration $[\mu \mathrm{M}]$

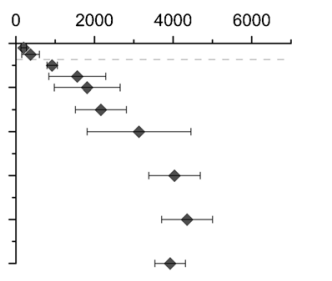

) $\mathrm{O}_{2}$ concentration [\% air sat.]
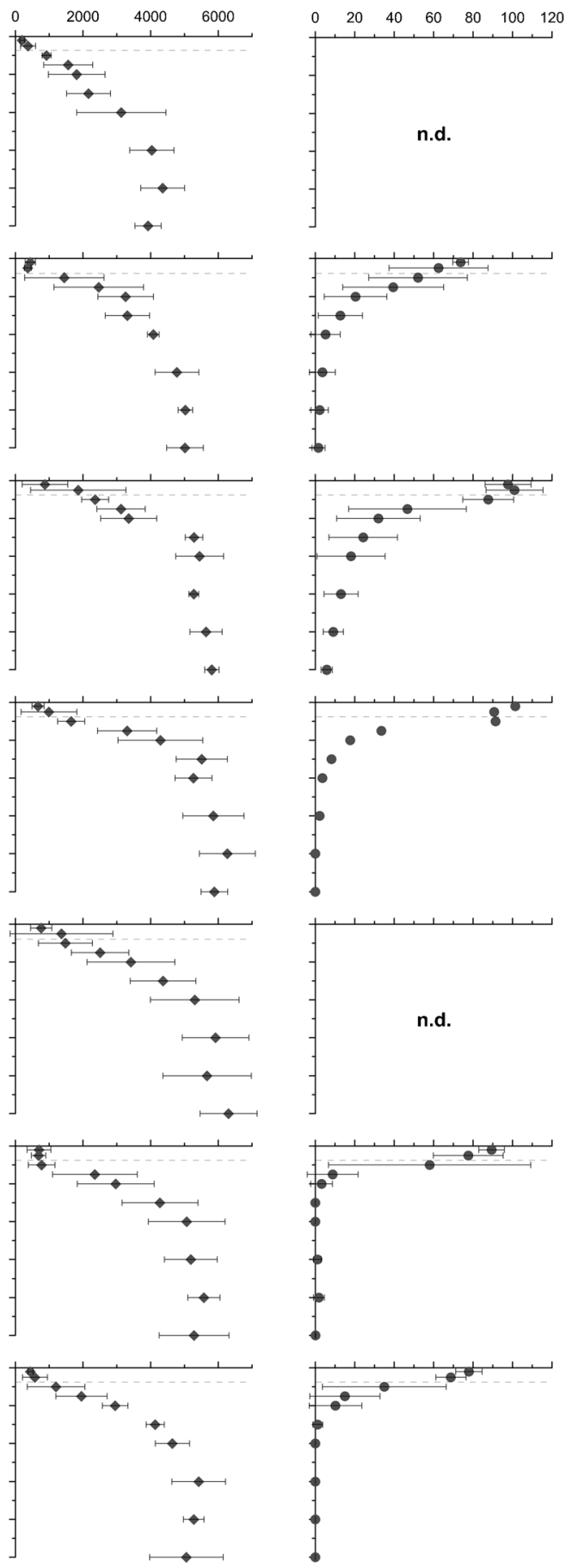

particularly pronounced between 5 and $15 \mathrm{~cm}$ depth. In July and early August, the pore water appeared to be oxygenated even in deeper layers, and $\mathrm{O}_{2}$ concentrations were generally higher compared with the later sampling dates, where the pore water was already anoxic from $15 \mathrm{~cm}$ down. A clear trend along the snow-free period was not observed, but measurements could not be taken on all sampling dates.

\section{Physico-Chemical Properties of Surface and Pore Water}

Water temperatures varied significantly $(F=38.5, p<0.001)$ between the sampling dates. In particular, the temperature of the surface water fluctuated considerably with a high of $25^{\circ} \mathrm{C}$ (Jul 18) and a low of $5{ }^{\circ} \mathrm{C}$ (Oct 22) (Fig. 3a), but it was generally clearly above the air temperature, except for the last two sampling dates. In the near-surface layers of the soil (5- 
$10 \mathrm{~cm}$ depth) temperatures were also quite variable, with values measured from June to August being generally higher and values measured in September and October being lower compared with temperatures in the deeper layers. From $15 \mathrm{~cm}$ down, temperatures were rather constant along the depth profiles. Average temperatures between 15 and $50 \mathrm{~cm}$ depth thereby increased between Jun $26\left(7.9 \pm 0.1^{\circ} \mathrm{C}\right)$ and Aug $23(13.0 \pm$ $1.0{ }^{\circ} \mathrm{C}$ ), followed by a decrease to $5.2 \pm 0.1{ }^{\circ} \mathrm{C}$ on Oct 22 .

Dissolved organic carbon concentrations were generally low, ranging from $1.7 \pm 1.4$ (Jun 26 at $40 \mathrm{~cm}$ depth) to $7.9 \pm$ $1.3 \mathrm{mg} \mathrm{L}^{-1}$ (Aug 23 at $1 \mathrm{~cm}$ depth), but varied significantly ( $F=13.3, p<0.001$ ) between sampling dates (Fig. 3b). Overall lower concentrations were noticed early (Jun 26) and late (Sep 25 and Oct 22) in the snow-free period compared with July and August, however a clear pattern was not discerned. On several sampling dates, high concentrations were observed in the surface water, while lowest values were mostly measured in the $10-15 \mathrm{~cm}$ depth pore water samples followed by a slight, but generally not significant increase with depth.

The $\mathrm{pH}$ of the pore water was acidic and varied little between sampling dates (Fig. 3c). In particular, samples collected between 20 and $50 \mathrm{~cm}$ depth were rather similar, with an overall average across sampling dates and depth of $4.9 \pm 0.3$. Variation was mainly observed at shallower depth $(5-10 \mathrm{~cm})$, where a neutral $\mathrm{pH}$ was measured in few individual samples. Electrical conductivity of the pore water also showed little variation between the sampling dates, but generally increased significantly along the depth profile $[\rho=0.943-1.000, p<0.05$; using mean values $(n=2-4)$ at each depth $(n=6)]$ (Fig. $3 \mathrm{~d})$. Values were rather low, ranging from $9.6 \pm 2.9 \mu \mathrm{S} \mathrm{cm}^{-1}$ at $5 \mathrm{~cm}$ depth to $22.1 \pm 2.6 \mu \mathrm{S} \mathrm{cm}^{-1}$ in the deepest samples (mean of all sampling dates).

\section{Correlation Between $\mathrm{CH}_{4}$ Emission or NEE and $C$. Rostrata Biomass}

Methane emissions were positively correlated $(r=0.707$, $p<0.001$ ) with the green $C$. rostrata biomass enclosed inside the individual chambers. The observed variation in emission within each sampling date was generally higher when the biomass inside the different chambers was also quite variable. Values of NEE were overall negatively correlated $(r=-0.554$, $p<0.01$ ) with the green $C$. rostrata biomass, meaning higher uptake was observed when more biomass was present.

The influence of the above-ground biomass of $C$. rostrata on $\mathrm{CH}_{4}$ emission and NEE was further assessed on selected dates in August and September by measuring fluxes after cutting the plants ca. $2 \mathrm{~cm}$ above the water table and subsequently ca. $1 \mathrm{~cm}$ below the water table. Methane emissions were not affected after cutting the biomass $2 \mathrm{~cm}$ above the water table, but dropped considerably after cutting the plants below the water table (11-16\% of emissions with full biomass; Table 2). In contrast, NEE values changed substantially when the plants were cut $2 \mathrm{~cm}$ above the water table: Several chambers showed reduced net $\mathrm{CO}_{2}$ uptake (5-54\% of net uptake with full biomass), while other chambers showed net $\mathrm{CO}_{2}$ emission of 37.8-109.2 $\mathrm{mg} \mathrm{CO}_{2} \mathrm{~m}^{-2} \mathrm{~h}^{-1}$. After complete cutting of the plants, overall net $\mathrm{CO}_{2}$ emission was observed. However, net $\mathrm{CO}_{2}$ uptake was still observed in individual chambers, and results were highly variable between and within sampling dates.

\section{Correlation Between $\mathrm{CH}_{4}$ Emission or NEE and Environmental Properties}

Profiles of dissolved $\mathrm{CH}_{4}$ and DIC pore water concentrations suggest zones of methanogenesis and $\mathrm{CO}_{2}$ production in the deeper layers below $15 \mathrm{~cm}$. We therefore assessed the correlations of mean pore water properties measured between 15 and $50 \mathrm{~cm}$ and $\mathrm{CH}_{4}$ emissions and NEE, respectively, observed at the different sampling dates. A positive correlation was noted between $\mathrm{CH}_{4}$ emissions and mean subsurface temperatures $(r=0.391, p<0.05)$. This correlation was more pronounced $(r=0.556, p<0.01)$ when the high emissions measured after snowmelt (Jun 26) were excluded from the calculations. However, a significant correlation between air temperatures during the time chamber incubations with $\mathrm{CH}_{4}$ emissions was not observed. Moreover, neither mean $\mathrm{CH}_{4}$ nor mean DOC pore water concentrations at the different sampling dates were correlated with the measured emissions.

Values of NEE were negatively correlated with mean subsurface temperatures below $15 \mathrm{~cm}$ depth $(r=-0.557$, $p<0.001$ ), suggesting higher net $\mathrm{CO}_{2}$ uptake with higher subsurface temperatures, while a significant correlation with air temperatures during chamber measurements was not observed. Similar to $\mathrm{CH}_{4}$, DIC concentrations in the pore water also suggest zones of $\mathrm{CO}_{2}$ production below $15 \mathrm{~cm}$. However, a correlation between mean DIC or mean DOC pore water concentrations between 15 and $50 \mathrm{~cm}$ depth and measured NEE was not observed.

\section{Discussion}

\section{Methodology}

The aim of the present study was to assess variability of $\mathrm{CH}_{4}$ emissions and NEE in a Swiss alpine fen over the snow-free vegetation period. Various methods are available to measure $\mathrm{CH}_{4}$ and $\mathrm{CO}_{2}$ dynamics, ranging from passive remote sensing satellite spectrometer (Buchwitz et al. 2005) and aircraft measurements (Merbold et al. 2013) to micrometeorological methods such as eddy covariance (Baldocchi 2003; Eugster and Plüss 2010) or static and dynamic flux chambers. These methods vary greatly in spatial and temporal resolution. For example, eddy covariance can provide continuous 
a) Temperature $\left[{ }^{\circ} \mathrm{C}\right]$
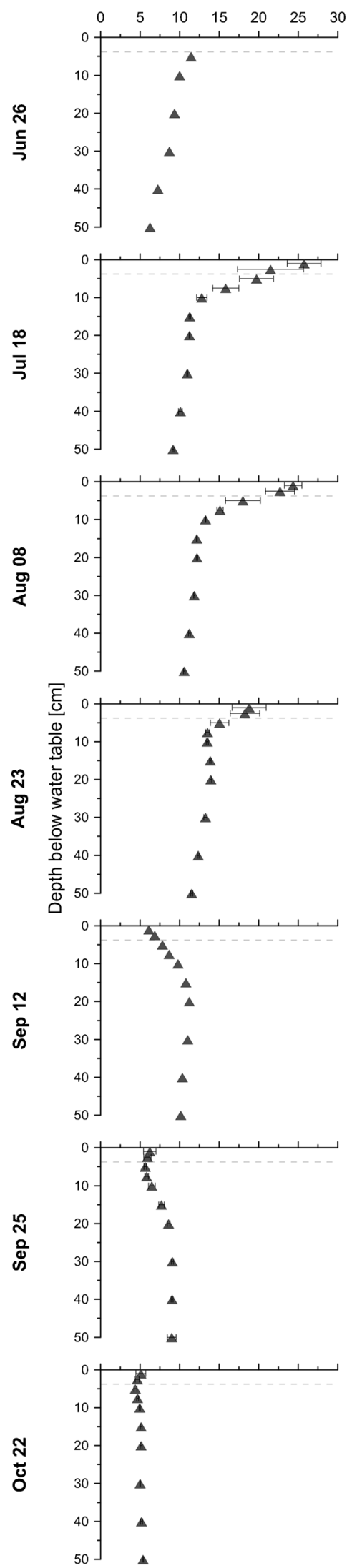

b)

DOC [ $\mathrm{mg} \mathrm{L}^{-1}$ ]
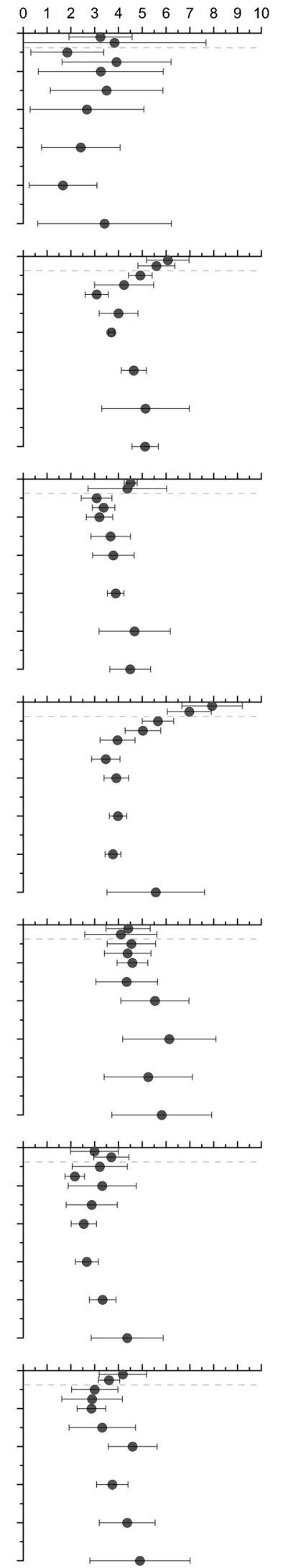

c)
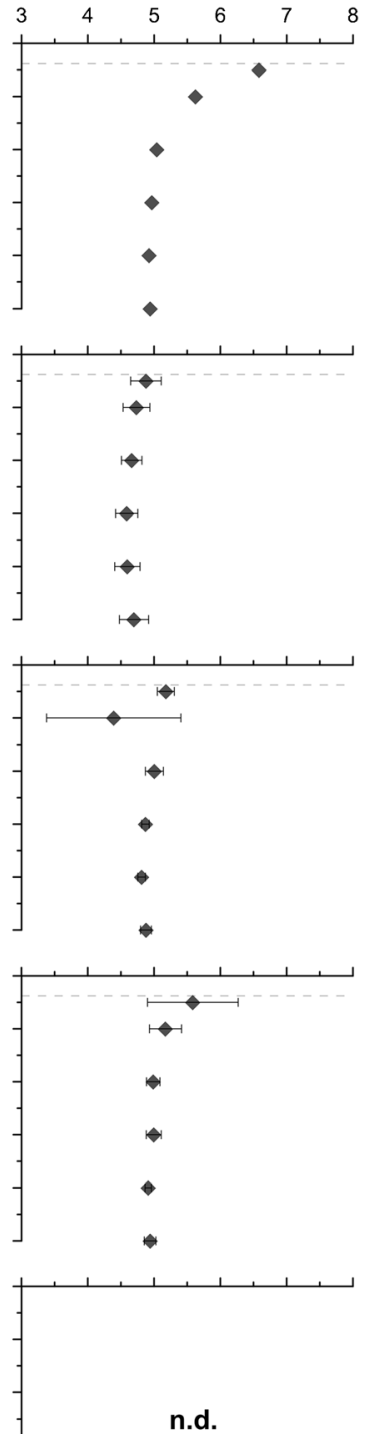

n.d.

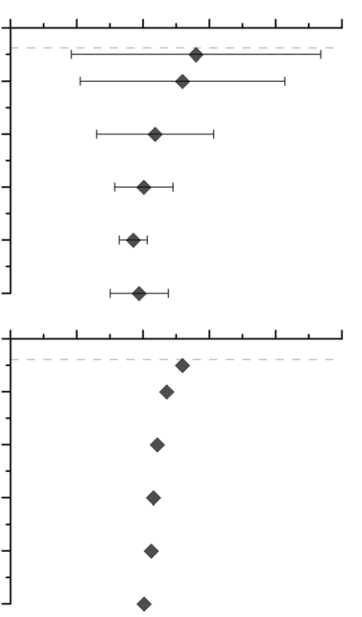

d) Elect. conductivity $\left[\mu \mathrm{S} \mathrm{cm}^{-1}\right]$
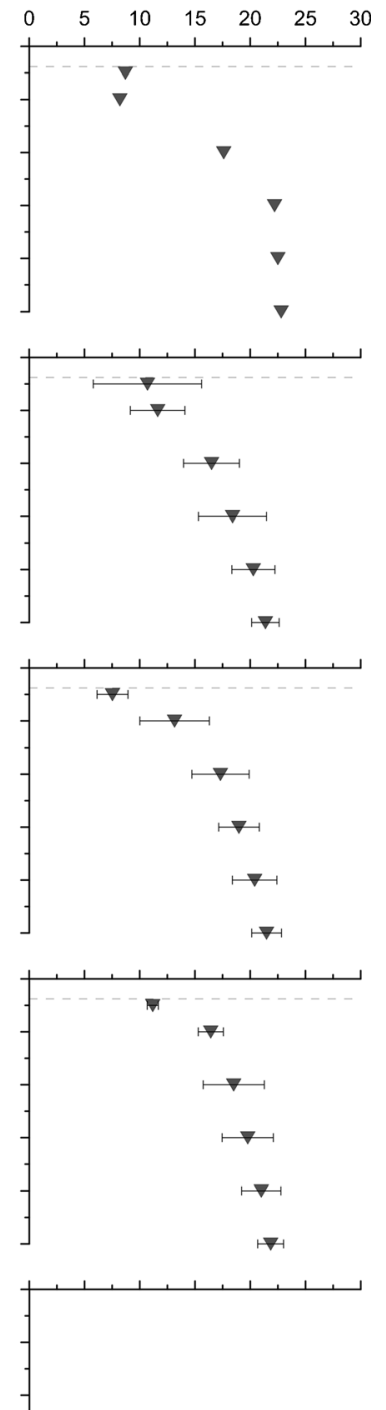

n.d.

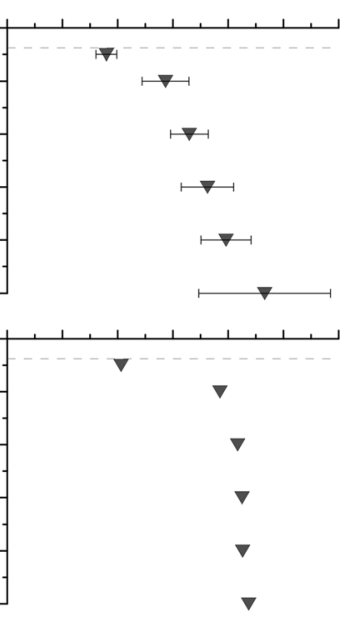


Fig. 3 Depth profiles of temperature (a), dissolved organic carbon (DOC) concentration (b), $\mathrm{pH}(\mathbf{c})$, and electrical conductivity (d) of the surface and pore water. Dotted lines indicate approx. position of the soil surface. Error bars denote standard deviation $(n=4)$; please note that measurements were done only at two positions for $\mathrm{pH}$ and electrical conductivity on Jun 26 and Oct 22, and for temperature on Jun 26 and Sep 12, and thus no error bars are displayed; n.d.: not done

measurements of averaged fluxes at the ecosystem scale $\left(10^{3}-\right.$ $10^{5} \mathrm{~m}^{2}$ ) (e.g., Lafleur et al. 2003; Morin et al. 2014), but is less suitable for systems with non-uniform vegetation or complex topography (Almand-Hunter et al. 2015). In such systems, for example in mountainous regions, chamber measurements can provide information on soil gas fluxes at high spatial resolution $\left(\mathrm{cm}^{2}-\mathrm{m}^{2}\right)$ (Lai et al. 2012).

Various automated and temperature-controlled chamber systems are available to date (e.g., Drewitt et al. 2002; Bergeron et al. 2009; Almand-Hunter et al. 2015). Yet, in alpine wetlands mostly manual chambers are employed (e.g., Wickland et al. 2001; Kato et al. 2011; Franchini et al. 2014). These chambers are light-weight and do not require a power source, which limits disturbance to the system. In our control experiments we could demonstrate that at the Oberaar fen temperature changes inside simple closed chambers during incubation were minimal, and thus temperature control was not required. Moreover, pressure peaks during deployment or pressure changes inside the chambers during incubation were not observed, and mixing of the air inside the chamber did not affect the deduced fluxes of $\mathrm{CH}_{4}$ and $\mathrm{CO}_{2}$. Recently, Lai et al. (2012) reported underestimation of fluxes from a porous peat land by chamber measurements. The authors attributed this underestimation to flushing of porous near-surface soils outside the chambers by low winds. At the Oberaar fen the soil is constantly submerged with a water table of 4-5 cm above the soil, and flushing of the system by low winds is likely negligible. Thus, our simple, static flux chambers can be considered valid tools to estimate $\mathrm{CH}_{4}$ emissions and NEE at this particular site.

During chamber measurements we allowed for equilibration of 5 min prior to collection of the first headspace gas sample to account for potential disturbances during chamber deployment (e.g., disturbance of the water table). Further control experiments however showed that $\mathrm{CO}_{2}$ is rapidly depleted inside the chambers within the initial 5-10 min. By taking the first sample $5 \mathrm{~min}$ after chamber deployment we potentially underestimated the absolute values of NEE by ca. $20 \%$ in comparison to sampling after $0.5 \mathrm{~min}$ (calculated based on eight control experiments; data not shown). Nevertheless, the pattern observed in our current study over the snow-free period (see below) is likely not affected by this underestimation.

\section{Selection of Study Site and Sampling Location}

High spatial variability in $\mathrm{CH}_{4}$ emissions and pore water concentrations has been reported from different fens in the Swiss Alps (Franchini et al. 2014). However, we measured comparable $\mathrm{CH}_{4}$ emissions at the Oberaar fen during summer over several years (Franchini et al. 2014 and 2015; Cheema et al. 2015). This indicates that the system is rather stable in space and time, making it an ideal site to study variability over the snow-free period.

Access to sampling locations within the Oberaar fen is limited without excessive disturbance to the system. Chamber measurements and sampling were therefore performed within a small area in the centre rather than at random positions in the fen. Around this location the water table level was quite stable over several years, and the distribution of C. rostrata was representative for the majority of the fen and appeared to be rather homogenous (Fig. S1). Still, assessment of the total biomass of the well-established plant community in August and early September revealed some above-ground heterogeneity in plant distribution. Thus, cluster sampling and subsequent autocorrelation during this study cannot fully be excluded (de Gruijter et al. 2006). Nevertheless, C. rostrata seemed to be the only sedge present at all sampling positions. It is therefore unlikely that observed variations in $\mathrm{CH}_{4}$ emissions and NEE were influenced by plant species-specific differences in $\mathrm{CH}_{4}$ emissions and photosynthesis rates reported for various Cyperaceae (Ding et al. 2005; Ström et al. 2005; Bhullar et al. 2013; Cheema et al. 2015).
Table 2 Effect of biomass removal on $\mathrm{CH}_{4}$ emission: Methane emissions at selected time points after cutting of $C$. rostrata biomass ca. $2 \mathrm{~cm}$ above the water table and ca. $1 \mathrm{~cm}$ below the water table. Emissions are shown relative to emissions measured at the same position with full biomass immediately prior to cutting. Values represent averages of four measurements \pm standard deviation

\begin{tabular}{llll}
\hline Sampling date & \multicolumn{2}{l}{$\mathrm{CH}_{4}$ flux } & \\
\cline { 2 - 4 } & Full biomass & Cut 2 cm above water table & Cut 1 cm below water table \\
\hline Aug 08 & 1.00 & $0.95 \pm 0.21$ & $0.12 \pm 0.08$ \\
Aug 23 & 1.00 & $1.04 \pm 0.35$ & $0.16 \pm 0.05$ \\
Sep 25 & 1.00 & $1.11 \pm 0.23$ & $0.11 \pm 0.06$ \\
\hline
\end{tabular}




\section{Variability of $\mathrm{CH}_{4}$ Emissions}

Our sampling location in the Oberaar fen appeared to be a daytime source of $\mathrm{CH}_{4}$ throughout the snow-free vegetation period, and emissions were positively correlated with the green above-ground $C$. rostrata biomass and mean subsurface temperatures. With the exception of the first sampling date, $\mathrm{CH}_{4}$ emissions and biomass increased to Aug 8, followed by a decrease from Sep 12 to the end of the snow-free period, and similar patterns have been reported previously from other alpine fens (e.g., Wickland et al. 2001; Hirota et al. 2004; Koch et al. 2007; Liebner et al. 2012). The exceptionally high emission despite low biomass shortly after snowmelt can be attributed to accumulation of $\mathrm{CH}_{4}$ in the subsurface during winter (see further discussion below).

Correlations between biomass and $\mathrm{CH}_{4}$ emissions have been ascribed mainly to the role of vascular plants as conduits for the direct release of $\mathrm{CH}_{4}$ (e.g., King et al. 1998; Joabsson et al. 1999). The biomass removal experiments in the present study and other unpublished studies at the Oberaar fen (data not shown) highlight this chimney effect and suggest that at least $84 \%$ of the total $\mathrm{CH}_{4}$ emissions measured inside the chambers result from transport through the plants' aerenchyma. Higher above-ground biomass likely also increases root exudates and subsequently substrates for methanogenesis (King and Reeburgh 2002; Saarnio et al. 2004). In our study, DOC pore water concentrations did not follow the pattern of the green biomass over the snow-free period. However, these concentrations do not represent turnover rates but the steadystate concentrations.

Apart from biomass, we recently also identified mean $\mathrm{CH}_{4}$ pore water concentrations at $0-20 \mathrm{~cm}$ depth as a factor correlated with spatial variability in $\mathrm{CH}_{4}$ emissions from 14 different wetlands in the Swiss Alps (Franchini et al. 2014a). At the Oberaar fen, correlations between $\mathrm{CH}_{4}$ emissions and mean pore water concentrations in different depth intervals $(0$ $15 \mathrm{~cm}, 5-15 \mathrm{~cm}$, or $15-50 \mathrm{~cm}$ ) were not discerned over the snow-free period. It cannot be excluded that other (potentially unknown) environmental factors differed between the 14 fens analysed in the pervious study, and thus influenced $\mathrm{CH}_{4}$ emissions. For example, a recent meta-analysis reported a high temperature dependence of seasonal variations in $\mathrm{CH}_{4}$ emissions from various aquatic and terrestrial ecosystems, similar to temperature dependence of $\mathrm{CH}_{4}$ production from methanogenic cultures (Yvon-Durocher et al. 2014). This is in agreement with the present study, in which a correlation between $\mathrm{CH}_{4}$ emissions and subsurface temperatures was also observed.

\section{Variability of $\mathrm{CO}_{2}$ net Ecosystem Exchange}

Overall, our sampling location was a sink for $\mathrm{CO}_{2}$ during midday (11:30 am-2:30 pm) throughout most of the snow- free period. As green biomass is the main driver for photosynthesis and thus $\mathrm{CO}_{2}$ uptake, NEE was also correlated with the green $C$. rostrata biomass. Only late in the snow-free vegetation period, NEE became positive, suggesting that rates of total respiration were higher compared with photosynthesis mediated by senescing plants. Variations in NEE within sampling dates were highest early and late in the snow-free period, when the biomass was not yet well established or started to senesce.

Photosynthesis not only depends on plant biomass, but also on light and to some degree on temperature (Thomas et al. 1996; Shaver et al. 1998). While a correlation between NEE values and air temperatures during chamber measurements was not discerned in our study, the observed variations in NEE might be affected by varying levels of irradiation. In fact, global radiation measured at the nearby WMO station varied between and sometimes also within sampling dates. We are aware that the WMO station is $6 \mathrm{~km}$ away from the Oberaar fen and that irradiation measured at this station might not fully reflect at the conditions at study site. However, published relationships between photosynthesis rates and light intensity generally show a rectangular hyperbolic function, i.e., photosynthesis rates can reach a maximum value at relatively low levels of irradiation (Ruimy et al. 1995). In the present study similar biomass but contrasting meteorological conditions were observed on Aug 08 and Sep 12, with the latter showing rain and ca. $85 \%$ lower levels of irradiation at the nearby WMO station. Yet, the measured value of NEE on Sep 12 was only reduced by ca. $20 \%$ compared with Aug 08 . Additional experiments were performed at the Oberaar fen at a later time point on a partially sunny, partially cloudy day in August, and irradiation was measured directly at the sampling location. Results showed that light intensity was reduced by ca. $40 \%$ under cloud cover, while photosynthesis rates were only reduced by ca. $5 \%$. This observation suggests that variation in irradiation, particularly within and between the five (partially) sunny sampling days, likely had little influence on the observed variation in NEE in the present study.

\section{Variability of Pore Water Properties}

During the snow-free period $\mathrm{O}_{2}$ diffuses from the atmosphere through the surface water into the subsurface. Particularly in July and August the convex and concave shapes of the $\mathrm{O}_{2}$ and $\mathrm{CH}_{4}$ steady-state pore water concentrations between 5 and $15 \mathrm{~cm}$ depth suggest that this $\mathrm{O}_{2}$ is rapidly consumed by methanotrophic bacteria. However, $\mathrm{CH}_{4}$ oxidation is incomplete and traces of $\mathrm{CH}_{4}$ diffuse into the surface water. In July and August the mean $\mathrm{CH}_{4}$ concentration in the surface water at $1 \mathrm{~cm}$ depth was around $2.1 \mu \mathrm{M}$. Considering a Henry's coefficient for $\mathrm{CH}_{4}$ of 27.2 (Stumm and Morgan 1981), a temperature of $20{ }^{\circ} \mathrm{C}$, and an elevation of $2,300 \mathrm{~m}$ a.s.l., a theoretical equilibrium concentration of ca. $1,850 \mathrm{ppmv}^{\mathrm{CH}_{4}}$ 
in the atmosphere can be calculated (Schwarzenbach et al. 2003). Considering that the atmospheric $\mathrm{CH}_{4}$ concentration in only ca. $1.8 \mathrm{ppmv}$, a direct flux of $\mathrm{CH}_{4}$ from the surface water into the atmosphere can be assumed in addition to the plant mediated transport. This is in agreement with the observed residual $\mathrm{CH}_{4}$ emissions measured after removal of the aerenchymous plants. The fact that the atmospheric $\mathrm{CH}_{4}$ concentration is far below the equilibrium concentration also explains why the $\mathrm{CH}_{4}$ concentrations in the flux chambers linearly increase over prolonged incubation times without signs of saturation.

The pore water concentrations of $\mathrm{CH}_{4}$ and $\mathrm{CO}_{2}$ (i.e., DIC) showed a pronounced variability over the snow-free period. Even though the observed pattern did not correlate with changes of the respective net fluxes, this variability can also largely be ascribed to changes in C. rostrata biomass. During winter, the snow cover provides insulation, and the subsurface temperatures do not fall below $0{ }^{\circ} \mathrm{C}$ (data not shown; Liebner et al. 2012). Thus, methanogenesis can proceed throughout winter in soil layers below $20 \mathrm{~cm}$. However, the absence of photosynthetically active plants, and consequently the limited $\mathrm{O}_{2}$ supply in the rhizosphere reduce aerobic $\mathrm{CH}_{4}$ oxidation and microbial mineralization of soil organic matter (i.e., $\mathrm{CO}_{2}$ production). In addition, snow cover and absence of aerenchymous plants also reduce $\mathrm{CH}_{4}$ emissions from the subsurface to the atmosphere, and only low levels of $\mathrm{CH}_{4}$ emission have been reported from snow-covered wetland systems (e.g., Sommerfeld et al. 1993; Koch et al. 2007; Chen et al. 2008). As a consequence, all these factors explain why high $\mathrm{CH}_{4}$ but low $\mathrm{CO}_{2}$ pore water concentrations were observed at the beginning of the snow-free period. With snow melt and the establishing plant community the accumulated $\mathrm{CH}_{4}$ is released through the plants' aerenchyma and the surface water, resulting in the exceptionally high $\mathrm{CH}_{4}$ emissions observed in June. Moreover, $\mathrm{O}_{2}$ is transported to the rhizosphere, facilitating aerobic $\mathrm{CH}_{4}$ oxidation and mineralization of soil organic matter and root exudates. These processes eventually lead to rather stable $\mathrm{CH}_{4}$ and $\mathrm{CO}_{2}$ pore water concentration profiles in the rhizosphere below $20 \mathrm{~cm}$ depth throughout the second half of the snow-free period.

Acknowledgments We are grateful to P. Nauer and M. Schroth for help with the flux calculations, and F. Ugolini for help with the DOC measurements. Furthermore we would like to thank C.E. Hoffman, M. Aeppli, I. Erny, B. Sunarjo, S. Vogel, M. Meola and É. Mészáros for the valuable help with lab and field work. We are particularly grateful to A. Lazzaro for help with statistical calculations.

\section{References}

Aerts R, Ludwig F (1997) Water-table changes and nutritional status affect trace gas emissions from laboratory columns of peatland soils. Soil Biol Biochem 29:1691-1698
Almand-Hunter BB, Walker JT, Masson NP, Hafford L, Hannigan MP (2015) Development and validation of inexpensive, automated, dynamic flux chambers. Atmos Measure Tech 8:267-280

Armstrong W, Justin SHFW, Beckett PM, Lythe S (1991) Root adaptation to soil waterlogging. Aqua Botany 39:57-73

Baldocchi DD (2003) Assessing the eddy covariance technique for evaluating carbon dioxide exchange rates of ecosystems: past, present and future. Glob Chang Biol 9:479-492

Bellisario LM, Bubier JL, Moore TR, Chanton JP (1999) Controls on $\mathrm{CH}_{4}$ emissions from a northern peatland. Global Biogeochem Cycles 13:81-91

Bergeron O, Margolis HA, Coursolle C (2009) Forest floor carbon exchange of a boreal black spruce forest in eastern North America. Biogeosci 6:1849-1864

Bhullar GS, Edwards PJ, Venterink HO (2013) Variation in the plantmediated methane transport and its importance for methane emission from intact wetland peat mesocosms. J Plant Ecol 6:298-304

Blodau C (2002) Carbon cycling in peatlands - A review of processes and controls. Environ Rev 10:111-134

Blodau C, Basiliko N, Moore TR (2004) Carbon turnover in peatland mesocosms exposed to different water table levels. Biogeochem 67:331-351

Buchwitz M, de Beek R, Burrows JP et al (2005) Atmospheric methane and carbon dioxide from SCIAMACHY satellite data: initial comparison with chemistry and transport models. Atmos Chem Phys 5: 941-962

Cao GM, Xu XL, Long RJ, Wang QL, Wang CT, Du YG, Zhao XQ (2008) Methane emissions by alpine plant communities in the Qinghai-Tibet Plateau. Biol Lett 4:681-684

Cheema S, Zeyer J, Henneberger R (2015) Methanotrophic and methanogenic communities in Swiss alpine fens dominated by Carex rostrata and Eriophorum angustifolium. Appl Environ Microbiol 81:5832-5844

Chen H, Yao SP, Wu N, Wang YF, Luo P, Tian JQ, Gao YH, Sun G (2008) Determinants influencing seasonal variations of methane emissions from alpine wetlands in Zoige Plateau and their implications. J Geophys Res Atmos 113:D12303. doi:10.1029/2006JD008072

Chen H, Wu N, Wang Y, Gao Y, Peng C (2011) Methane fluxes from alpine wetlands of Zoige Plateau in relation to water regime and vegetation under two scales. Water Air Soil Pollut 217:173-183

Chimner RA, Cooper DJ (2003) Carbon dynamics of pristine and hydrologically modified fens in the southern Rocky Mountains. Can J Bot $81: 477-491$

Christensen TR, Jonasson S, Callaghan TV, Havstrom M (1995) Spatial variation in high-latitude methane flux along a transect across Siberian and European tundra environments. J Geophys Res Atmos 100:21035-21045

Ciais P, Sabine C, Bala G et al (2013) Carbon and other biogeochemical cycles. In: Stocker TF, Qin D, Plattner G-K, Tignor M, Allen SK, Boschung J, Nauels A, Xia Y, Bex V, Midgley PM (eds) Climate change 2013: the physical science basis. Contribution of working group I to the fifth assessment report of the intergovernmental panel on climate change. Cambridge University Press, Cambridge, pp $465-552$

Conrad R (1996) Soil microorganisms as controllers of atmospheric trace gases $\left(\mathrm{H}_{2}, \mathrm{CO}, \mathrm{CH}_{4}, \mathrm{OCS}, \mathrm{N}_{2} \mathrm{O}\right.$, and $\left.\mathrm{NO}\right)$. Microbiol Rev 60:609640

De Gruijter JJ, Burs DJ, Bierkens MFP, Knotters M (2006) Sampling for natural resource monitoring. Springer, Berlin

Denman KL, Brasseur A, Chidthaisong A et al (2007) Couplings between changes in the climate system and biogeochemistry. In: Solomon S, Qin D, Manning M, Chen Z, Marquis M, Averyt KB, Tignor M, Miller HL (eds) Climate Change 2007: the physical science basis. Contribution of working group I to the fourth assessment report of the intergovernmental panel on climate change. Cambridge University Press, Cambridge, pp 500-587 
Development Core Team R (2012) R: a language and environment for statistical computing. R Foundation for Statistical Computing, Vienna

Ding WX, Cai ZC, Tsuruta H (2005) Plant species effects on methane emissions from freshwater marshes. Atmos Environ 39:3199-3207

Drewitt GB, Black TA, Nesic Z, Humphreys ER, Jork EM, Swanson R, Ethier GJ, Griffis T, Morgenstern K (2002) Measuring forest floor $\mathrm{CO}_{2}$ fluxes in a Douglas-fir forest. Agr Forest Meteorol 110:299 317

Eugster W, Plüss P (2010) A fault-tolerant eddy covariance system for measuring $\mathrm{CH}_{4}$ fluxes. Agr Forest Meteorol 150:841-851

Franchini AG, Erny I, Zeyer J (2014) Spatial variability of methane emissions from Swiss alpine fens. Wetland Ecol Manag 22:383-397

Franchini AG, Henneberger R, Aeppli M, Zeyer J (2015) Methane dynamics in an alpine fen: a field based study on methanogenic and methanotrophic microbial communities. FEMS Microbiol Ecol 91: fiu032. doi:10.1093/femsec/fiu032

Gorham E (1991) Northern peatlands - Role in the carbon-cycle and probable responses to climatic warming. Ecol Appl 1:182-195

Green SM, Baird AJ (2011) A mesocosm study of the role of the sedge Eriophorum angustifolium in the efflux of methane - including that due to episodic ebullition - from peatlands. Plant and Soil 351:207218

Hirota M, Tang YH, Hu QW, Hirata S, Kato T, Mo WH, Cao GM, Mariko S (2004) Methane emissions from different vegetation zones in a Qinghai-Tibetan Plateau wetland. Soil Biol Biochem 36:737-748

Hirota M, Tang YH, Hu QW, Hirata S, Kato T, Mo WH, Cao GM, Mariko S (2006) Carbon dioxide dynamics and controls in a deep-water wetland on the Qinghai-Tibetan Plateau. Ecosystems 9:673-688

Joabsson A, Christensen TR (2001) Methane emissions from wetlands and their relationship with vascular plants: an arctic example. Glob Chang Biol 7:919-932

Joabsson A, Christensen TR, Wallen B (1999) Vascular plant controls on methane emissions from northern peatforming wetlands. Trends Ecol Evol 14:385-388

KatoT HM, Tang Y, Wada E (2011) Spatial variability of $\mathrm{CH}_{4}$ and $\mathrm{N}_{2} \mathrm{O}$ fluxes in alpine ecosystems on the Qinghai-Tibetan Plateau. Atmos Environ 45:5632-5639

King JY, Reeburgh WS (2002) A pulse-labeling experiment to determine the contribution of recent plant photosynthates to net methane emission in arctic wet sedge tundra. Soil Biol Biochem 34:173-180

King JY, Reeburgh WS, Regli SK (1998) Methane emission and transport by arctic sedges in Alaska: results of a vegetation removal experiment. J Geophys Res 103:29083-29092

Koch O, Tscherko D, Kandeler E (2007) Seasonal and diurnal net methane emissions from organic soils of the Eastern Alps, Austria: effects of soil temperature, water balance, and plant biomass. Arctic Antarctic Alpine Res 39:438-448

Koch O, Tscherko D, Kuppers M, Kandeler E (2008) Interannual ecosystem $\mathrm{CO}_{2}$ dynamics in the alpine zone of the Eastern Alps, Austria. Arctic Antarctic Alpine Res 40:487-496

Koelbener A, Ström L, Edwards PJ, Olde Venterink H (2010) Plant species from mesotrophic wetlands cause relatively high methane emissions from peat soil. Plant and Soil 326:147-158

Körner C (1999) Alpine plant life. Springer, Berlin

Kutzbach L, Wagner D, Pfeiffer EM (2004) Effect of microrelief and vegetation on methane emission from wet polygonal tundra, Lena Delta, Northern Siberia. Biogeochem 69:341-362

Lafleur PM, Roulet NT, Bubier JL, Frolking S, Moore TR (2003) Interannual variability in the peatland-atmosphere carbon dioxide exchange at an ombrotrophic bog. Global Biogeochem Cycles 17: 1036

Lai DYF, Roulet NT, Humphreys ET, Moore TR, Dalva M (2012) The effect of atmospheric turbulence and chamber deployment period on autochamber $\mathrm{CO}_{2}$ and $\mathrm{CH}_{4}$ flux measurements in an ombrotrophic peatland. Biogeosci 9:3305-3322
Laine AM, Bubier J, Riutta T, Nilsson MB, Moore TR, Vasander H, Tuittila ES (2012) Abundance and composition of plant biomass as potential controls for mire net ecosytem $\mathrm{CO}_{2}$ exchange. Botan Botanique 90:63-74

Liebner S, Schwarzenbach SP, Zeyer J (2012) Methane emissions from an alpine fen in central Switzerland. Biogeochem 109:287-299

McEwing KR, Fisher JP, Zona D (2015) Environmental and vegetation controls on the spatial variability of $\mathrm{CH} 4$ emissions from wet-sedge and tussock tundra ecosystems in the Arctic. Plant Soil 388:37-52

Merbold L, Steinlin C, Hagedorn F (2013) Winter greenhouse gas fluxes $\left(\mathrm{CO}_{2}, \mathrm{CH}_{4}\right.$ and $\left.\mathrm{N}_{2} \mathrm{O}\right)$ from a subalpine grassland. Biogeosci 10: 3185-3203

Mitra S, Wassmann R, Vlek PLG (2005) An appraisal of global wetland area and its organic carbon stock. Curr Sci 88:25-35

Moore T, Basiliko N (2006) Decomposition in boreal peatlands. In: Wieder RK, Vitt D (eds) Boreal peatland ecosystems. Ecological studies, vol 188. Springer, Berlin, pp 125-143

Morin TH, Bohrer G, Frasson RPDM, Naor-Azreli L, Mesi S, Stefanik KC, Schafer KVR (2014) Environmental drivers of methane fluxes from an urban temperate wetland park. J Geophys Res Biogeosc 119:2188-2208

Oberbauer SF, Gillespie CT, Cheng W, Gebauer R, Serra AS, Tenhunen JD (1992) Environmental effects on $\mathrm{CO}_{2}$ efflux from riparian tundra in the northern foothills of the Brooks Range, Alaska, USA. Oecologia 92:568-577

Pocock T, Krol M, Huner NPA (2004) The determination and quantification of photosynthetic pigments by reverse phase high-performance liquid chromatography, thin-layer chromatography, and spectrophotometry. In: Carpentier R (ed) Methods in molecular biology, vol 274. Humana Press, New York pp 137-148

Porra RJ (2006) Spectrometric assays for plant, algal and bacterial chlorophylls. In: Grimm B, Porra RG, Ruduger W (eds) Advances in photosynthesis and respiration. Springer, Berlin, pp 95-107

Ruimy A, Jarvis PG, Baldocchi DD, Saugier B (1995) $\mathrm{CO}_{2}$ fluxes over plant canopies and solar radiation: a review. In: Begon M, Fitter A (eds) Advances in ecological research, vol 26. Elsevier, Amsterdam, pp 1-68

Rustad LE, Huntington TG, Boone RF (2000) Controls on soil respiration: implications for climate change. Biogeochem 48:7-20

Saarnio S, Wittenmayer L, Merbach W (2004) Rhizospheric exudation of Eriophorum vaginatum L. - Potential link to methanogenesis. Plant and Soil 267:343-355

Schlesinger WH (1997) Biogeochemistry: an analysis of global change, $2^{\text {nd }}$ edn. Academic Press, Waltham

Schwarzenbach RP, Gschwend PM, Imboden DM (2003) Environmental chemistry, 2nd edn. Wiley, New York

Shaver GR, Johnson LC, Cades DH, Murray G, Laundre JA, Rastetter EG, Nadelhoffer KJ, Giblin AE (1998) Biomass and $\mathrm{CO}_{2}$ flux in wet sedge tundras: responses to nutrients, temperature, and light. Ecol Monograph 68:75-97

Sommerfeld RA, Mosier AR, Musselman RC (1993) $\mathrm{CO}_{2}, \mathrm{CH}_{4}$ and $\mathrm{N}_{2} \mathrm{O}$ flux through a Wyoming snowpack and implications for global budgets. Nature 361:140-142

Ström L, Ekberg A, Mastepanov M, Christensen TR (2003) The effect of vascular plants on carbon turnover and methane emissions from a tundra wetland. Glob Chang Biol 9:1185-1192

Ström L, Mastepanov M, Christensen TR (2005) Species-specific effects of vascular plants on carbon turnover and methane emissions from wetlands. Biogeochem 75:65-82

Stumm W, Morgan JJ (1981) Aquatic chemistry: an introduction emphasizing chemical equilibria in natural waters, 2 nd edn. Wiley, New York

Thomas KL, Benstead J, Davies KL, Lloyd D (1996) Role of wetland plants in the diurnal control of $\mathrm{CH}_{4}$ and $\mathrm{CO}_{2}$ fluxes in peat. Soil Biol Biochem 28:17-23 
van der Nat FJWA, Middelburg JJ (1998) Seasonal variation in methane oxidation by the rhizosphere of Phragmites australis and Scirpus lacustris. Aqua Botany 61:95-110

von Fischer JC, Rhew RC, Ames GM, Fosdick BK, von Fischer PE (2010) Vegetation height and other controls of spatial variability in methane emissions from the Arctic coastal tundra at Barrow, Alaska. J Geophys Res 115:G00I03. doi:10.1029/2009JG001283

West AE, Brooks PD, Fisk MC, Smith LK, Holland EA, Jaeger CH, Babcock S, Lai RS, Schmidt SK (1999) Landscape patterns of $\mathrm{CH}_{4}$ fluxes in an alpine tundra ecosystem. Biogeochem 45:243-264

Whalen SC (2005) Biogeochemistry of methane exchange between natural wetlands and the atmosphere. Environ Eng Sci 22:73-94
Wickland KP, Striegl RG, Mast MA, Clow DW (2001) Carbon gas exchange at a southern Rocky Mountain wetland, 1996-1998. Global Biogeochem Cycles 15:321-335

Windell JT, Willard BE, Cooper DJ, Foster SQ, Knud-Hansen CF, Rink LP, Kiladis GN (1986) An ecological characterization of Rocky Mountain montane and subalpline wetlands. U.S. Fishery and Wildlife Services, Washington DC

Yvon-Durocher G, Allen AP, Bastviken D, Conrad R, Gudasz C, StPierre A, Thanh-Duc N, del Giorgio PA (2014) Methane fluxes show consistent temperature dependence across microbial to ecosystem scales. Nature 507:488-491 